103.

\title{
CT 検査時の被瞵線量に線質が与える影要
}

Influence on effective energy for patient exposure of CT examinations 藤田保揵衙生大学 ○鈴木昇一、藤井茂久、折户武郎 藤田保硉衛生大学病院 井田義宏 SS 技研株式会社 加藤秀起

（目的）CT 俟查は今や一般 X 線挨查に欠かせないものになってきた。またCT を応用したヘリカル方式の検查やCT 透視法

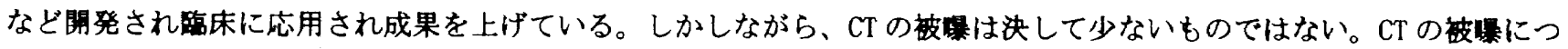
いても多くの研究が行われ公表されている。我々は、本大学で開発された CT 透視法の被嚗を中心に線兵との関保におい て入射表面と内部の分布がどのように変化するかを検討した。

（方法）東芝製 XVigor を使用して、通常の梌查に使用される線管（管圧 $120 \mathrm{kV} ）$ と CT 透視 $(80 \mathrm{kV})$ で使用される線 質での入射表面、 $1 \mathrm{~cm}$ 深さ、回転中心等の線量測定し、比㜞した。また、管菓圧 $100 \mathrm{kV} 、 135 \mathrm{kV}$ 及び装贯に装着されている 被嚗低減つィルタを使用したときも同様に測定した。

(結果) 通常の腹部検査で使用する管電圧 $120 \mathrm{kV}$ と CT 透視で使用する $80 \mathrm{kV}$ (フィルタなし)では同一管㫣流時間䋖 (mAs 值）で比した場合、線量は $80 \mathrm{kV}$ の約 4 倍、入射表面で約 6 倍であった。通常の腹部 $\mathrm{CT}(120 \mathrm{kV}, 200 \mathrm{~mA}, 1 \mathrm{sec})$ とCT 透視 $(80 \mathrm{kV}, 30 \mathrm{~mA}, 10 \mathrm{sec})$ では中心部で 2.5 倍、入射表面で反対に $1 / 8$ に減少した。半価層は、管電圧 $120 \mathrm{kV}$ において HVLで約 $10 \mathrm{mmAl}(64 \mathrm{keV}) 、 80 \mathrm{kV}$ で $3 \mathrm{mmAl}(35 \mathrm{keV})$ 程度であった。

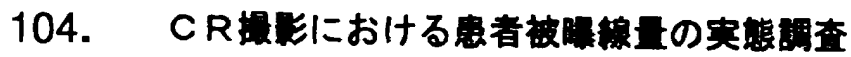

Study of Patient Dose in Computed Radiography

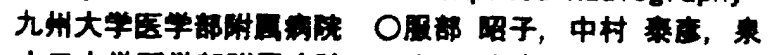

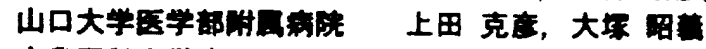

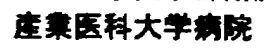
小田 钴弘

\author{
鼓, 小宽

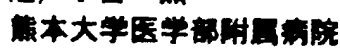 \\ 干代田テクノル
}

羽手村 昌宏 小迫 管略

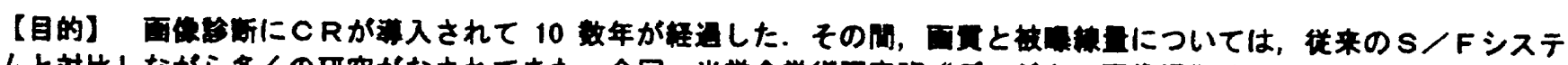

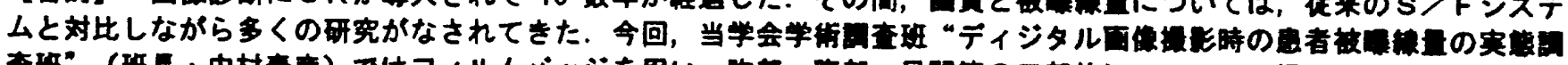

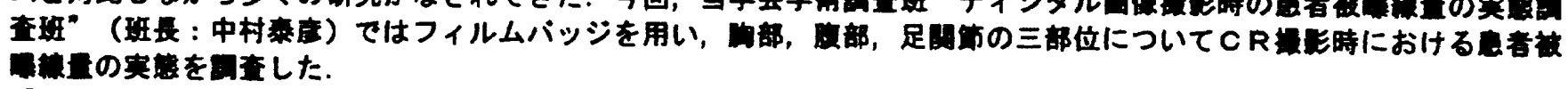

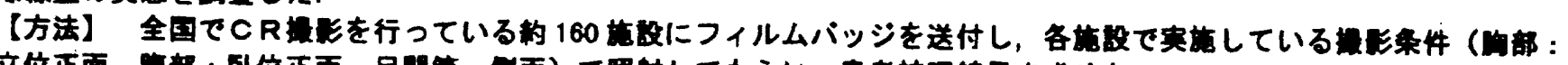

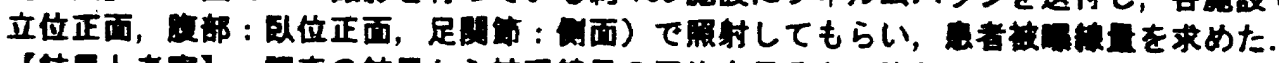

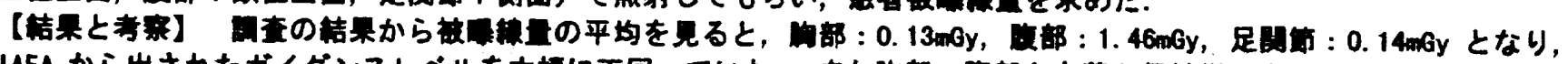

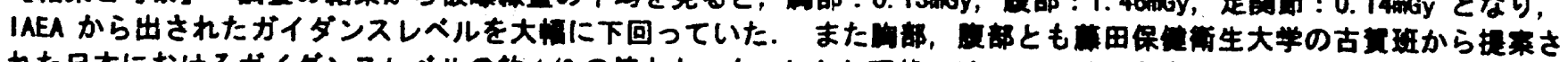

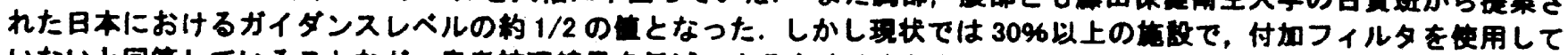

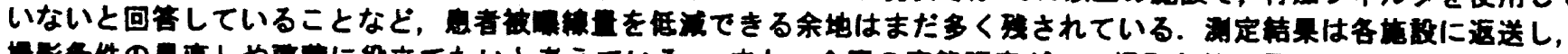

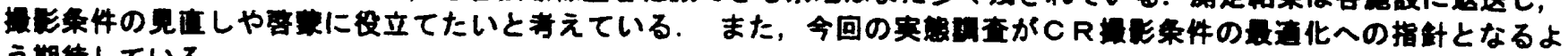
う期待している.

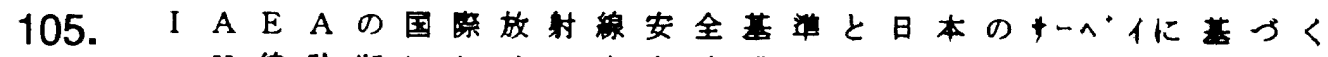

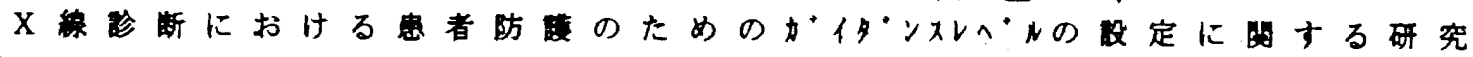
Study on a guidance level based on Japanese survey for protection of patients in diagnostic radiology.

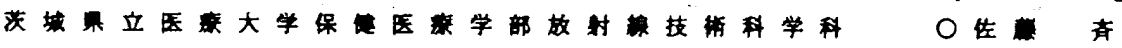

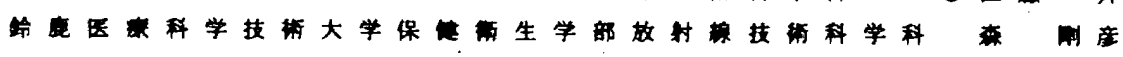

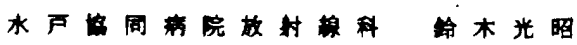

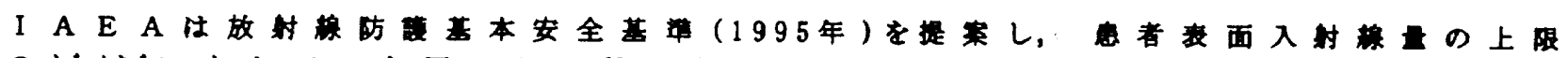

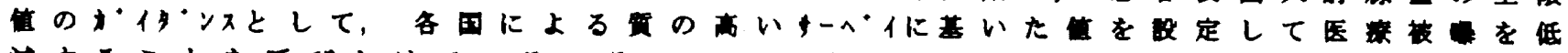

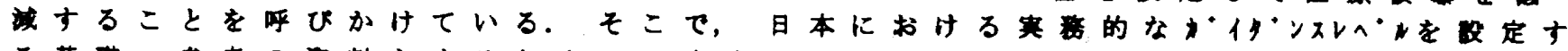

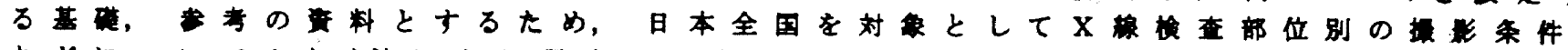

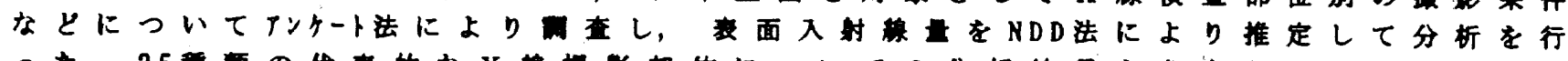

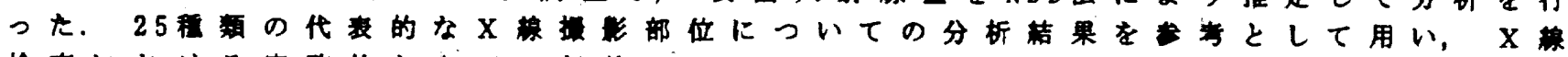

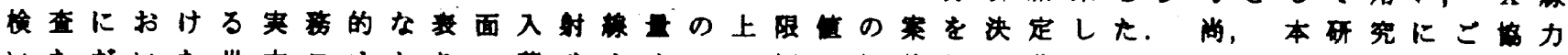

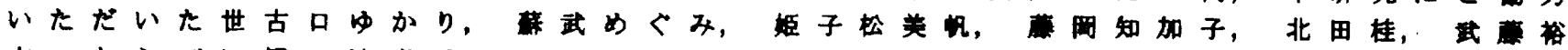

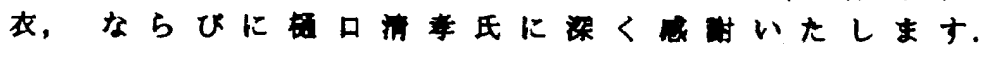

